\title{
The Effect of Shuttle Drill Training on the Ability of Dribbling Ball in Soccer Games in Extracuricular Students of Sma Negeri 1 Lembak
}

\author{
Maya Kurnia ", Putri Cicilia Kristina, Husni Fahritsani, Perabu Nita, Hengki Kumbara, Daryono \\ Department of Sports Education, Faculty of Teaching and Education Science, Universitas PGRI Palembang, Palembang, Indonesia
}

Received September 22, 2020; Revised December 24, 2020; Accepted January 6, 2021

\begin{abstract}
Cite This Paper in the following Citation Styles
(a): [1] Maya Kurnia, Putri Cicilia Kristina, Husni Fahritsani, Perabu Nita, Hengki Kumbara, Daryono, "The Effect of Shuttle Drill Training on the Ability of Dribbling Ball in Soccer Games in Extracuricular Students of Sma Negeri 1 Lembak," International Journal of Human Movement and Sports Sciences, Vol. 9, No. 1, pp. 110-116, 2021. DOI: 10.13189/saj.2021.090115.
\end{abstract}

(b): Maya Kurnia, Putri Cicilia Kristina, Husni Fahritsani, Perabu Nita, Hengki Kumbara, Daryono (2021). The Effect of Shuttle Drill Training on the Ability of Dribbling Ball in Soccer Games in Extracuricular Students of Sma Negeri 1 Lembak. International Journal of Human Movement and Sports Sciences, 9(1), 110-116. DOI: 10.13189/saj.2021.090115.

Copyright $\bigcirc 2021$ by authors, all rights reserved. Authors agree that this article remains permanently open access under the terms of the Creative Commons Attribution License 4.0 International License

\begin{abstract}
The problem in this study is that there is an effect of shuttle drill training on the ability to dribble in extracurricular students at SMA Negeri 1 Lembak. This study aims to determine the effect of shuttle drill running on the ability to dribble in soccer games for extracurricular students at SMA Negeri 1 Lembak. This type of research is experimental research, using the one group pretest-posttest design method. The population in this study was 30 SMA Negeri 1 Lembak soccer players, while the sample in this study amounted to 20 people. The sampling technique used in this study was purposive sampling technique. The data collection technique used the dribbling or dribbling test method. The data analysis technique used the t-test formula. Based on the results of research conducted on football extracurricular students at SMA Negeri 1 Lembak, the average pretest result was 26.45 seconds and the posttest average was 19.55 . This shows that shuttle drill practice can improve students' dribble skills in playing soccer football extracurricular activity at SMA Negeri 1 Lembak. Because there is an increase after being given treatment compared to before being given treatment. In testing the hypothesis, the value of $t$-count $>\mathrm{t}$-table or $16.33>1.73$ is obtained, so it can be concluded that there is an effect of shuttle drill training on the ability to dribble in soccer games for extracurricular students of SMA Negeri 1
\end{abstract}

Lembak.

Keywords Shuttle Drill, Dribbling, Football Games

\section{Introduction}

Football is something common among people of different backgrounds, a bridge that connects economic, political, cultural and religious levels. Known as "football" almost all over the world, football is a national sport in almost all countries in Asia, Africa, Europe and South America. This sport is the only type of football game played at the Olympics. Millions more people choose to watch the Super Bowl and World Series. Without a doubt, football is the most famous game (Luxbacher, 2011: 1). Exercise is the process of preparing physically and mentally train children systematically to achieve the optimal performance quality with given the burden of regular practice, directed, increased, and repeatedly the time (Samsudin, 2017).

Sports began in the 2nd and 3rd century BC in China, during the Han Dynasty. Similar games in Japan and Italy Modern football began to develop in England and were 
very popular. The development made soccer more and more famous in the university and school environment. During the 1800s the sport was brought by British sailors, merchants and soldiers to various parts of the world. In 1904, the highest association of world football (FIFA) was formed in the 1900s. (Saraswati dan Juanda, 2013:8)

Football is the most famous sport in the world. More than 200 million people around the world play more than 20 million football games each year. To give an idea of the popularity of football, more than 2 billion television viewers watched the Brazilian team beat Italy in the 1994 world final. The development of soccer in Indonesia is also growing rapidly. This was marked by the establishment of the Indonesian Football Association (PSSI) in 1930 in Yogyakarta known to Soeratin Sosrosoegondo. To appreciate his services, starting in 1996 a Soeratin Cup soccer championship was held, which is a soccer championship for youth cadets. At that time the game of football was favored by almost all levels of society in Indonesia (Kurniawan, 2012: 76).

In the game of football, techniques and skills are needed to be mastered in playing soccer. Techniques in soccer games include passing, shooting, heading, control, goal geeping and dribbling. One of them is dribbling, dribbling (dribbling) must be done with good and correct technique. Dribbling is like taking a short kick, but the ball is near the feet. Usually this technique is done to approach a target or target with past several opponents who are ready to block (Rahmani, 2014: 101).

One of the SMA Negeri 1 Lembak coaching programs which have carried out extracurricular activities has been well implemented, including in the field of soccer which is fostered by sports teachers PJOK (Physical Education, Sports and Health). This football extracurricular activity has not been maximal because it was seen that there were students who did not master the techniques in the soccer game in the form of dribbling techniques. Training methods to improve dribbling skills in soccer require proper dribbling techniques to get maximum results.

Soccer is a game played by two teams of 11 people each. This sport is very well known and is played in 200 countries. The game of football aims to score as many goals as possible using leather balls measuring 27-28 inches (Atmasubrata, 2012: 78).

The game of football is one of the most popular sports in the world. The number played by 11 people with the aim of scoring goals against opponents. Every player has the same duty and role, which must be able to attack and defend well, according to Martha (Ngolo \& Ohoirot, 2018: 31).

From the theory above, the researchers concluded that soccer is a sport played by 11 people. This game aims to create as many goals as possible against your opponents. In addition, football is a game that is very popular with people from young to old.

In soccer games, players should master the basic techniques of playing soccer well. According to Mirman (Samsudin, 2017: 3) basic techniques are no less important, because mastery of basic techniques will show the ability and beauty of a soccer player when playing the ball. Without mastering the basic techniques well, the game will not be created well, because basic techniques are important in soccer in addition to physicality.

\subsection{Basic Technique of Dribbling}

Dribbling is a technique of carrying the ball using your feet while moving. According to Mielke (Aprianova, 2016: 64) the technique of dribbling is a basic skill in football because the player must be able to control the ball while moving, standing, or acting in passing or shooting. The dribbling technique is basically dribbled foot. Many soccer players have the ability to dribble above average, even with their excellent dribbling ability becomes easier to get past the opponent when the ball is over (Wahyu Jayadi, et al. 2015).

\subsection{The Basic Technique of Kicking a Ball}

Primarily, the participant's soccer game must be able to kick the ball. The skill of kicking or kicking the ball is very important for performing various other techniques in the game. According to Mielke (Aprianova, 2016: 64) technique is the mastery of the basic skills of kicking a ball.

\subsection{Technique to Control the Ball}

The trapping technique is a method of controlling the ball that is most often used by players while playing on the field and receiving balls from other players according to Mielke (Aprianova, 2016: 64). This technique is a basic technique that every player must master because controlling the ball must be done properly if you want the game to be good.

\subsection{Technique Heading the Ball}

Players can do headings while shooting, jumping, forward, dropping (diving), or staying still by pointing the ball sharply at a goal or a teammate according to Mielke (in Aprianova, 2016: 64). The technique of heading the ball is often used by the players when the ball is high so that players can head the ball in the direction it is aimed.

\subsection{The Essence of Dribbling}

In soccer games players should master the basic techniques of playing soccer well. According to Mirman (Samsudin, 2017: 3) basic techniques are no less important, because mastery of basic techniques will show the ability and beauty of a soccer player when playing the 
ball. Without mastering the basic techniques properly, the game will not be created well, because basic techniques are important in soccer in addition to physicality.

Dribbling is a method of moving the ball from one point to another on the court using your feet. Dribbling is a basic skill in soccer because all players must be able to control the ball while moving, standing or preparing to make passes or shots. When players have mastered their dribbling skills effectively, their contribution to the match will be very large (Samsudin, 2017: 3).

Not everyone can dribble well. the basic technique of good dribbling must do the way in which the foot with the ball must be close to match the dribbling technique, according to Luxbacher (in Aprianova, 2017: 64) dribbling in football has the same function as basketball, which is allowing to defend the ball while running across an opponent or advancing into an open space can use different parts of the leg.

The ability to dribble in soccer games is a basic skill that must be mastered by soccer players. With the ability to dribble well. A player can pass the opponent easily and then provide bait or shoot at the opponent's goal (Lukman, 2019: 2).

From some of the above theories, the researcher concludes that dribbling is a technique in soccer games that must be mastered by all soccer players. If a player does the dribbling technique well, the player's contribution is very large in this soccer game.

\subsection{The Nature of Shuttle Drill}

Exercise or training is a systematic practice process that is carried out repeatedly. And every day the number of training loads increases (Samsudin, 2017: 2). According to (Harsono, 2017: 50) training or training is a systematic process of practicing or working. Which is $\mathrm{N}$ done repeatedly with the day increasing the load of training or work. Exercise is an exercise material designed and developed by a trainer for one practice session or one-on-one in the exercise. It is therefore important that the trainer understands and applies the Individualization principle to the implementation of the exercise program activity (Radita Dwi Candra, 2015).

\subsubsection{Practice Principles}

What athletes bring out is a reflection of what the coach has given in training (Harsono, 2015: 37). There are several principles that need to be considered in the training process. According to Suharno (Samsudin, 2017: 2) said that to accelerate the achievement of training goals, there are several things that need to be considered, namely: a) exercise must be as long as diligent,b) increase training load regularly, c) the principle of stress (pressure/over load), d) individual principle, e) interval (repetition) principle, f) principle (food nutrition), g) principle of extensive and intensive training, h) principle of overall improvement.

\subsubsection{Training Goals}

The main goals and objectives of training are to help athletes to improve their skills and achievements as much as possible (Harsono, 2015: 39). To increase one's potential and ability development, so that someone who does the exercise systematically or regularly can achieve the highest biomotor ability level.

Shuttle Drill is a form of training that combines speed and agility to develop a player's or student's agility. This exercise requires people to make movements quickly and change direction quickly. This activity or this exercise should not lose progress and one should know the position of the body when doing the exercise.

\section{Material and Method}

\subsection{Material}

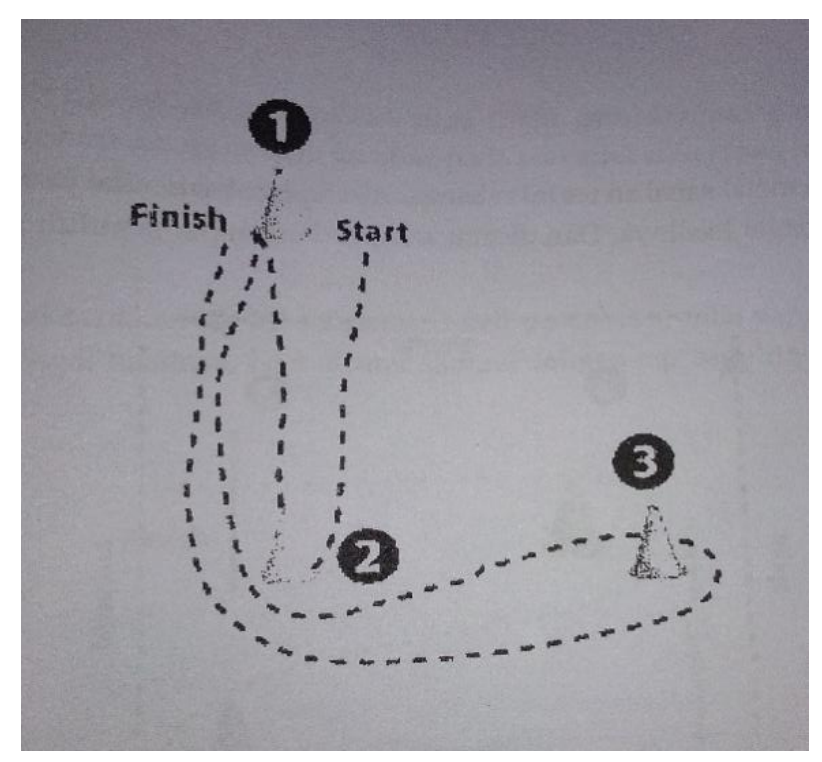

Figure 1. Shuttle Drill (Widiastuti, 2016)

\section{The landing used:}
a). Stopwatch
b). Meter
c). A flat, non-slip floor
d). 3 cones / cones

\section{Implementation:}

The athlete or student stands behind the line while running towards cone two. Then the athlete or student runs a curve towards the cone with one hand touching the cone, then runs a curve through cone three and then returns to the finish line. (Widiastuti, 2015: 154-155). 


\subsection{Methods}

The research method is defined as a scientific way to obtain data with specific purposes and uses (Sugiyono, 2010: 3). This research method uses experimental method. This method is used to find out whether or not the effect of the treatment variable, namely shuttle drills training, on the ability to dribble in extracurricular students at SMA Negeri 1 Lembak.

The method in this research is the Pre-experimental Group Design, namely the One-Group Pretest-posttest Design (pretest-posttest) one group. The data collection technique in this study was to do a dribble test on football extracurricular students at SMA Negeri 1 Lembak.

The sample of the study was extracurricular football players at SMA Negeri 1 Lembak. In this study, from a population of 30 players, 20 players were selected by means of purposive sampling.

\section{Results}

Table 1. Data on Results of the Pretest and Posttest of Dribble in Soccer Games

\begin{tabular}{|c|c|c|c|c|}
\hline \multirow{2}{*}{ No } & \multirow{2}{*}{$\begin{array}{l}\text { Students' } \\
\text { Name }\end{array}$} & \multicolumn{2}{|c|}{ Test Results } & \multirow{2}{*}{ Incremen } \\
\hline & & Prettest & Posttest & \\
\hline 1 & Resp. 1 & 28.4 & 18.8 & 9.6 \\
\hline 2 & Resp. 2 & 29.1 & 21.5 & 7.6 \\
\hline 3 & Resp. 3 & 28.3 & 17.1 & 11.2 \\
\hline 4 & Resp. 4 & 23.7 & 20.4 & 3.3 \\
\hline 5 & Resp. 5 & 24.6 & 19.8 & 4.8 \\
\hline 6 & Resp. 6 & 25.9 & 17.6 & 8.3 \\
\hline 7 & Resp. 7 & 26.2 & 18.9 & 7.3 \\
\hline 8 & Resp. 8 & 29.9 & 21.9 & 8 \\
\hline 9 & Resp. 9 & 30.4 & 22.2 & 8.2 \\
\hline 10 & Resp. 10 & 26.6 & 20.7 & 5.9 \\
\hline 11 & Resp. 11 & 24.7 & 20.1 & 4.6 \\
\hline 12 & Resp. 12 & 23.6 & 17.2 & 6.4 \\
\hline 13 & Resp. 13 & 26.2 & 19.6 & 6.6 \\
\hline 14 & Resp. 14 & 26.2 & 20.7 & 5.5 \\
\hline 15 & Resp. 15 & 25.1 & 19.5 & 5.6 \\
\hline 16 & Resp. 16 & 26.7 & 20.1 & 6.6 \\
\hline 17 & Resp. 17 & 31.8 & 22.4 & 9.4 \\
\hline 18 & Resp. 18 & 22.8 & 17.4 & 5.4 \\
\hline 19 & Resp. 19 & 22.5 & 16.1 & 6.4 \\
\hline 20 & Resp. 20 & 26.7 & 20.2 & 6.5 \\
\hline
\end{tabular}

Based on the table above, it can be concluded that the results of the posttest data assessment of the extracurricular ability of the students' soccer game dribbling at SMA Negeri 1 Lembak are better than the results of the pretest data assessment. This can be seen from the results of the increase in the dribble ability of the extracurricular soccer game students of SMA Negeri 1 Lembak.

The description of the results of the pretest data assessment of the dribble skills of the extracurricular soccer game students of SMA Negeri 1 Lembak can be described as follows:

1. Range $=$ Largest value - Smallest value

$$
\begin{gathered}
=31,8-22,5 \\
=9,3
\end{gathered}
$$

1. Banyak kelas $=1+3,3 \log n$

$$
\begin{gathered}
=1+3,3 \log 20 \\
=1+3,3(1,30) \\
=1+4,29 \\
=5,29 \approx 5
\end{gathered}
$$

\begin{tabular}{|c|c|c|c|c|c|c|}
\hline No & $\begin{array}{c}\text { Class } \\
\text { Interval }\end{array}$ & $F \boldsymbol{F}$ & $X i$ & $F i X i$ & $X i^{2}$ & $F i \cdot X i^{2}$ \\
\hline 1 & $22,5-24,4$ & 4 & 23,45 & 93,8 & 549,90 & 2199,61 \\
\hline 2 & $24,5-26,4$ & 7 & 25,45 & 178,15 & 647,70 & 4533,92 \\
\hline 3 & $26,5-28,4$ & 5 & 27,45 & 137,25 & 753,50 & 3767,51 \\
\hline 4 & $28,5-30,4$ & 3 & 29,45 & 88,35 & 867,30 & 2601,91 \\
\hline 5 & $30,5-32,4$ & 1 & 31,45 & 31,45 & 989,10 & 989,10 \\
\hline \multicolumn{2}{|r|}{ Total } & 20 & & 529 & 3807,51 & 14092,05 \\
\hline \multicolumn{2}{|c|}{ Rata-rata $\left(x^{-}\right)$} & \multicolumn{5}{|c|}{26,45} \\
\hline
\end{tabular}

\begin{tabular}{|c|c|c|c|}
\hline \multicolumn{4}{|c|}{ Pretest } \\
\hline No & Class Interval & Frequency & Percentage \\
\hline 1 & $22,5-24,4$ & 4 & $20 \%$ \\
\hline 2 & $24,5-26,4$ & 7 & $35 \%$ \\
\hline 3 & $26,5-28,4$ & 5 & $25 \%$ \\
\hline 4 & $28,5-30,4$ & 3 & $15 \%$ \\
\hline 5 & $30,5-32,4$ & 1 & $5 \%$ \\
\hline & Total & 20 & $100 \%$ \\
\hline
\end{tabular}

2. Panjang kelas $=\frac{\text { rentang }}{\text { banyak kelas }}$

$$
\begin{gathered}
=\frac{9,3}{5} \\
=1,86=1,9
\end{gathered}
$$

Table 2. List of Distribution of Preliminary Test Results (Pretest)

Table 3. Frequency Distribution of Soccer Game Dribble Pretest Data

Based on the table above, of the 20 samples, it was found that at the interval $22.5-24.4$ there were 4 students $(20 \%)$, while at the interval $24.5-26.4$ there were 7 students $(35 \%)$. In the $26.5-28.4$ interval there were 5 students $(25 \%)$, while at the $28.5-30.4$ interval there were 3 students (15\%) and at the $30.5-32.4$ interval there were 1 student $(5 \%)$. For more details, see the image below.

Description of the results of the assessment of the pretest data on the ability to play soccer dribbles 
extracurricular students of SMA Negeri 1 Lembak can be described as follows:

1. Range $=$ Largest value - Smallest value

$$
\begin{aligned}
& =22,4-16,1 \\
& =6,
\end{aligned}
$$

1. Banyak kelas $=1+3,3 \log n$

$$
\begin{aligned}
& =1+3,3 \log 20 \\
& =1+3,3(1,30) \\
& =1+4,29 \\
& =5,29 \approx 5
\end{aligned}
$$

\begin{tabular}{|c|c|c|c|c|c|c|}
\hline No & $\begin{array}{c}\text { Class } \\
\text { Interval }\end{array}$ & $F i$ & $X i$ & $F i X i$ & $X i^{2}$ & $\mathrm{Fi} \cdot \mathrm{Xi}^{2}$ \\
\hline 1 & $16,1-17,4$ & 4 & 16,75 & 67 & 280,56 & 1122,25 \\
\hline 2 & $17,5-18,8$ & 2 & 18,15 & 36,3 & 329,42 & 658,85 \\
\hline 3 & $18,9-20,2$ & 7 & 19,55 & 136,85 & 382,20 & 2675,42 \\
\hline 4 & $20,3-21,6$ & 4 & 20,95 & 83,8 & 438,90 & 1755,61 \\
\hline 5 & $21,7-23$ & 3 & 22,35 & 67,05 & 499,52 & 1498,57 \\
\hline \multicolumn{2}{|r|}{ Jumlah } & 20 & & 391 & 1930,61 & 7710,69 \\
\hline \multicolumn{2}{|c|}{ Rata-rata $\left(x^{-}\right)$} & \multicolumn{5}{|c|}{19,55} \\
\hline
\end{tabular}

2. Panjang kelas $=\frac{\text { rentang }}{\text { banyak kelas }}$

\begin{tabular}{|c|c|c|c|}
\hline \multicolumn{4}{|c|}{ Posttest } \\
\hline No & Class Interval & Frequency & Percentage \\
\hline 1 & $16,1-17,4$ & 4 & $20 \%$ \\
\hline 2 & $17,5-18,8$ & 2 & $10 \%$ \\
\hline 3 & $18,9-20,2$ & 7 & $35 \%$ \\
\hline 4 & $20,3-21,6$ & 4 & $20 \%$ \\
\hline 5 & $21,7-23$ & 3 & $15 \%$ \\
\hline & Total & 20 & $100 \%$ \\
\hline
\end{tabular}

$$
\begin{aligned}
& =\frac{6,3}{5} \\
& =1,26 \approx 1,3
\end{aligned}
$$

Table 4. Distribution List of Final Test Results (Posttest)
Table 5. Frequency Distribution of Dribble Posttest Data for Soccer Games

Based on the table above of the 20 samples, it was found that at the interval $16.1-17.4$ there were 4 students $(20 \%)$, while at the interval $17.5-18.8$ there were 2 students $(10 \%)$. In the $18.9-20.2$ interval there were 7 students $(35 \%)$, while at the $20.3-21.6$ interval there were 4 students $(20 \%)$ and at the $21.7-23$ interval there were 3 students $(15 \%)$. For more details, see the image below.

The data obtained from the results of the pretest and posttest dribble of football games for extracurricular

\begin{tabular}{|c|c|c|c|c|c|c|c|}
\hline \multirow{2}{*}{ No } & \multirow{2}{*}{ Students' Name } & \multicolumn{2}{|c|}{ Time } & \multirow{2}{*}{ d } & \multirow{2}{*}{$d^{2}$} & \multirow{2}{*}{$\begin{array}{c}\text { Xd } \\
\text { (d-Md) }\end{array}$} & \multirow{2}{*}{$\mathbf{X} d^{2}$} \\
\hline & & Pretest & Posttest & & & & \\
\hline 1 & Resp. 1 & 28.4 & 18.8 & 9.6 & 92.16 & 2.74 & 7.51 \\
\hline 2 & Resp. 2 & 29.1 & 21.5 & 7.6 & 57.76 & 0.74 & 0.55 \\
\hline 3 & Resp. 3 & 28.3 & 17.1 & 11.2 & 125.44 & 4.34 & 18.84 \\
\hline 4 & Resp. 4 & 23.7 & 20.4 & 3.3 & 10.89 & -3.56 & 12.67 \\
\hline 5 & Resp. 5 & 24.6 & 19.8 & 4.8 & 23.04 & -2.06 & 4.24 \\
\hline 6 & Resp. 6 & 25.9 & 17.6 & 8.3 & 68.89 & 1.44 & 2.07 \\
\hline 7 & Resp. 7 & 26.2 & 18.9 & 7.3 & 53.29 & 0.44 & 0.19 \\
\hline 8 & Resp. 8 & 29.9 & 21.9 & 8 & 64 & 1.14 & 1.30 \\
\hline 9 & Resp. 9 & 30.4 & 22.2 & 8.2 & 67.24 & 1.34 & 1.80 \\
\hline 10 & Resp. 10 & 26.6 & 20.7 & 5.9 & 34.81 & -0.96 & 0.92 \\
\hline 11 & Resp. 11 & 24.7 & 20.1 & 4.6 & 21.16 & -2.26 & 5.11 \\
\hline 12 & Resp. 12 & 23.6 & 17.2 & 6.4 & 40.96 & -0.46 & 0.21 \\
\hline 13 & Resp. 13 & 26.2 & 19.6 & 6.6 & 43.56 & -0.26 & 0.07 \\
\hline 14 & Resp. 14 & 26.2 & 20.7 & 5.5 & 30.25 & -1.36 & 1.85 \\
\hline 15 & Resp. 15 & 25.1 & 19.5 & 5.6 & 31.36 & -1.26 & 1.59 \\
\hline 16 & Resp. 16 & 26.7 & 20.1 & 6.6 & 43.56 & -0.26 & 0.07 \\
\hline 17 & Resp. 17 & 31.8 & 22.4 & 9.4 & 88.36 & 2.54 & 6.45 \\
\hline 18 & Resp. 18 & 22.8 & 17.4 & 5.4 & 29.16 & -1.46 & 2.13 \\
\hline 19 & Resp. 19 & 22.5 & 16.1 & 6.4 & 40.96 & -0.46 & 0.21 \\
\hline 20 & Resp. 20 & 26.7 & 20.2 & 6.5 & 42.25 & -0.36 & 0.13 \\
\hline \multicolumn{2}{|r|}{ Total } & 529.4 & 392.2 & 137.2 & 1009.1 & & 67.91 \\
\hline
\end{tabular}
students of SMA Negeri 1 Lembak will be used to test the hypothesis or significant research to determine the effect of shuttle drill running on the ability to dribble in soccer games for students, extracurricular activities at SMA Negeri 1 Lembak. Hypothesis testing or significant test in this study used statistical t-test.

Table 1. Pretest and Posttest Results 
Based on the table above, the hypothesis testing data analysis was carried out using the formula:

$$
t=M d \frac{M d}{S \sqrt{\frac{\sum x^{2} d}{N(N-1)}}}
$$

Nilai $M d=\frac{\sum d}{N}=\frac{137,2}{20}=6,86$

$$
\begin{gathered}
\sum x^{2} d=\sum d^{2}-\frac{\left(\sum d\right)^{2}}{N} \\
=1009,1-\frac{(137,2)^{2}}{20} \\
=1009,1-\frac{18823,84}{20} \\
=1009,1-941,192=67,91 \\
t=\frac{M d}{\sqrt{\frac{\sum x^{2} d}{N(N-1)}}} \\
t=\frac{6,86}{\sqrt{\frac{67,91}{20(20-1)}}} \\
t=\frac{6,86}{\sqrt{0,179}} \\
t=\frac{6,86}{0,42}=16,33
\end{gathered}
$$

Trust is taken $\alpha=5 \%$ with $\mathrm{t}(1-\alpha)=\mathrm{t}(0.95)$ or $95 \%$ so that the significant test of $\mathrm{t}$ table price at $\alpha=0.05$ with $\mathrm{dk}$ $=20-2=18$ obtained $\mathrm{t}$ table price $=1.73$.

The calculation above can be concluded that tcount $>$ ttable or 16.33>1.73, then Ho reject and accept Ha. Thus it can be concluded that there is an effect of Shuttle Drill running on the ability to dribble in soccer games for extracurricular students of SMA Negeri 1 Lembak.

\section{Discussion}

Based on the results of research that has been carried out on extracurricular students at SMA Negeri 1 Lembak, the average pretest or pretest results are 26.45 seconds with the best time for obtaining the dribble test is 22.5 seconds and the worst time is 31.8 seconds. Based on the results of the initial test or pretest of 20 samples, it was found that at the interval $22.5-24.4$ there were 4 students $(20 \%)$, while at the interval $24.5-26.4$ there were 7 students $(35 \%)$. At the $26.5-28.4$ interval there were 5 students $(25 \%)$, while at the $28.5-30.4$ interval there were 3 students $(15 \%)$ and at the 30.5 - 32.4 interval there was 1 student $(5 \%)$. Meanwhile, at the posttest the average obtained was 19.55 after the students were given shuttle drill training, the best time for obtaining the dribble test was 16.1 seconds and the worst time was 22.4 seconds.

Based on the results of the final test or posttest from 20 samples, it was found that at the interval $16.1-17.4$ there were 4 students $(20 \%)$, while at the interval $17.5-18.8$ there were 2 students $(10 \%)$. In the $18.9-20.2$ interval there were 7 students $(35 \%)$, while at the $20.3-21.6$ interval there were 4 students $(20 \%)$ and at the $21.7-23$ interval there were 3 students $(15 \%)$. After Initial test data (pretest) and final test (posttest) are obtained, then the normality test is carried out, and it can be stated that the data is normally distributed. Furthermore, the t-test results obtained with a value of 16.33 .

Judging from the results of calculations and data analysis that have been stated above, there is a significant effect after students are given shuttle drill exercises. At the initial or pretest test results an average of 26.45 seconds and at the posttest the average obtained 19.55 seconds. After calculating using the t-test, there is a result tcount $=16.33$, it can be concluded that tcount $>$ ttable or $16.33>1.73$, then $\mathrm{Ha}$ is accepted and Ho is rejected. Thus it can be concluded that there is an effect of Shuttle Drill running on the ability to dribble in soccer games for extracurricular students of SMA Negeri 1 Lembak.

\section{Conclusions}

Based on the results of research conducted on football extracurricular students at SMA Negeri 1 Lembak, the average pretest result was 26.45 seconds and the posttest average was 19.55 . This shows that the Shuttle Drill exercise can improve the dribble skills of playing soccer in football extracurricular students at SMA Negeri 1 Lembak. Because there is an increase after being given treatment compared to before being given treatment. In testing the hypothesis, the value of tcount $>$ ttable or 16.33> 1.73 is obtained, so it can be concluded that there is an effect of shuttle drill running on the ability to dribble in soccer games in extracurricular students of SMA Negeri 1 Lembak.

\section{REFERENCES}

[1] Luxbacher, Joseph A. 2011. Sepak bola. Jakarta: PT Raja Grafindo Persada.

[2] Kurniawan, Feri. 2012. Buku pintar pengetahuan olahraga. Jakarta Timur: Laskar Aksara.

[3] Ngolo, Hamid. Ohoirot, Mukhlis. 2018. Pengembangan model pembelajaran Passing permainan sepak bola di SMP Negeri 7 Wasilei Halmahera Timur.

[4] Atmasubrata, Ginanjar. 2012. Serba tahu dunia olahraga. Surabaya: Dafa Publishing.

[5] Rahmani, Mikanda. 2014. Buku super lengkap olahraga. Jakarta Timur: Dunia Cerdas.

[6] Saraswati, Desi. Juanda, Jho. 2013. Fakta sepak bola dunia. 
Jakarta: Be Champion (Penebar Swadaya Grup).

[7] Widiastuti. 2015. Tes dan Pengukuran olahraga. Jakarta: PT Raja Grafindo Persada.

[8] Harsono. 2015. Kepelatihan olahraga. Bandung: PT Remaja Rosdakarya.

[9] Samsudin. Furkan. 2017. Pengaruh Latihan kelincahan terhadap keterampilan menggiring bola dalam permainan sepak bola. Jurnal pendidikan olahraga. Vol 7. No (1).2-3.

[10] Lukman RA. Dkk. 2019. Tingkat keterampilan dribbling sepak bola pada SMP Al-Irsyad Surakarta. Bulletin literasi budaya sekolah. Vol 1, no(1): 2.

[11] Aprianova, Farid. 2016. Metode drill untuk meningkatkan teknik dasar menggiring bola (dribbling) dalam permanan sepak bola pada siswa sekolah sepak bola putra zodiac kabupaten bojonegoro usia 13-15 tahun. Jurnal kepelatihan olahraga. Vol 1. No (1): 64.
[12] Sugiyono. 2010. Metode Penelitian Pendidikan. Bandung: Ikapi

[13] Jayadi, W., Sukamto, \& Hasbunallah. (2015). Latihan Kelincahan dan Latihan Menggiring Bola pada Permainan Sepakbola. Jurnal Penelitian Pendidikan INSANI, 18(2), 137-142. Retrieved from http://ojs.unm.ac.id/Insani/article/ view/3642

[14] Samsudin, \& Furkan. (2017). Pengaruh Latihan Kelincahan terhadap Keterampilan Menggiring Bola dalam Permainan Sepakbola. Jurnal Pendidikan Olahraga,7(1). Retrieved from http://jurnal.lppmstkiptsb.ac.id/index.php/jpo/article/view/5

[15] Candra, R. D., Sulaiman, \&Hidayah, T. (2015). Pengaruh Metode Latihan dan Kemampuan Motor Educability terhadap Hasil Latihan Teknik Dasar Sepakbola. Journal of Physical Education and Sports, 4(2). Retrieved from https://journal.unnes.ac.id/artikel_sju/jpes/9888 